\title{
Farmers' dependency on forests for nutrients transfer to farmlands in mid-hills and high mountain regions in Nepal (case studies in Hemja, Kaski, Lete and Kunjo, Mustang district)
}

\author{
Mohan Krishna Balla ${ }^{1 *}$, Krishna Raj Tiwari ${ }^{1}$, Gandhiv Kafle ${ }^{1}$, Shrikrishna Gautam ${ }^{2}$, Shankar \\ Thapa $^{1}$ and Bandana Basnet ${ }^{1}$ \\ ${ }^{1}$ Institute of Forestry, Tribhuvan University, Pokhara Campus, Pokhara, Nepal. \\ ${ }^{2}$ Department of Forest Research and Survey, Babarmahal, Kathmandu, Nepal.
}

Accepted February 12, 2014

\begin{abstract}
The study assessed NPK (Nitrogen, Phosphorus, Potassium) transferred through litter from forest to farmlands, forest product extraction systems and farmers' perceptions on forest dependency for maintaining farm fertility in Lete and Kunjo, Mustang (high mountain) and Tibrekot, Kaski (mid-hill region), Nepal. NPK in composite samples of forest litter were determined by standard methods. Questionnaire survey of randomly selected households $(\mathrm{HH})(25 \%$ of 138 in Mustang and $14.15 \%$ of 212 HHs in Kaski), key informant survey and field observations were conducted to solicit socio-economic and resource use information. In Lete, each $\mathrm{HH}$ collected $582 \mathrm{~kg}$ Pinus wallichiana needles, made compost and transferred 3.84, 0.54 and $2.99 \mathrm{~kg} \mathrm{~N}, \mathrm{P}$ and $\mathrm{K}$ to 0.7965 ha whereas in Kunjo, each $\mathrm{HH}$ collected higher $(2162 \mathrm{~kg})$ which transferred $19.66,1.84$ and $10.39 \mathrm{~kg}$ respectively to $0.55 \mathrm{ha}$ farmlands per year, indicating higher dependency of Kunjo farmers for maintaining soil fertility. Forest product extraction was regulated by a local Conservation Area Management Committee consisting of ward representatives and Mukhiyas. All HHs depended on forest for maintaining soil fertility with $\mathbf{8 5 . 2 9 \%}$ totally depending on forest while $14.71 \%$ also used some chemical fertilizers. In Hemja, each $\mathrm{HH}$ collected $250 \mathrm{~kg}$ leaf litter of mainly Schima-Castonopsis and transferred $11.08,1.26$ and $5.86 \mathrm{~kg}$ of $\mathrm{N}, \mathrm{P}$ and $\mathrm{K}$ respectively, and $612 \mathrm{~kg}$ grass, transferred $16.27,2.22$ and $11.42 \mathrm{~kg}$ respectively per year to farmlands (0.1538 ha upland- Bari and 0.2383 lowland- Khet per $\mathrm{HH})$. The litter and grass collection was regulated by operational plan and constitution of Tibrekot Community Forest. In both regions, peoples' dependency on forest resources was decreasing (according to $73.5 \% \mathrm{HHs}$ in Mustang and $60 \%$ in Kaski) because of change in lifestyle and decrease in dependency on agriculture and livestock. Detailed study regarding effects of removal of leaf litter/grass on the functional aspect of forest ecosystem in the Nepalese context is recommended.
\end{abstract}

Key words: Soil fertility, leaf litter, community forest, compost, forest resources, Bari land, Khet land.

\section{INTRODUCTION}

In the mid-hills of Nepal where the majority of the population (about 85\%) is still dependent on agriculture
(CBS, 2005), maintenance and improvement of soil fertility is a prime concern. Mountain farming is heavily 
dependent on forest resources, such as leaf litter, green manure, poles, fuelwood, fodder, and non-timber forest products (Mahat, 1987; Thapa and Weber, 1995; Kadaria, 1992). According to Denholm (1991), between 3.5 and 6 ha of forestland are required to support each ha of crop land whereas the relations of agricultural to forest land are quantified by area as 1:2.8 (Wyatt-Smith, 1982). For hill farming systems to be sustainable, it primarily requires a net transfer of fertility from the forest through fodder and leaf-litter to stall-fed animals. The forest and crop biomass flow into cropland in the forms of organic residues/manure, mulch, animal feed and bedding materials via livestock (Griffin et al., 1988; Gilmour, 1989; Yadav, 1992). About $50 \%$ of leaf litter is removed from the mid-hill forests annually for composting purposes. Forests contribute more than $50 \%$ of the total fodder supply (Kadaria, 1994). The litter used as bedding material for livestock, along with fodder fed to livestock, is a major pathway for the nutrient flow from forest to agricultural land (Pilbeam et al., 2000; Aase et al., 2009, 2013). Rural farmers collect these materials from nearby forests to prepare the farmyard manure, which is the only source of soil organic carbon (SOC) and nutrient replenishment for sustainable farm productivity. Changes in the forest conditions have effects on nutrient transfer to farms and these can have major implications on change in livelihood of the farmers living near the forests.

The declining availability of forest-produced fodder and leaf-litter means that nutrient levels and soil structure cannot be maintained. Given the present rate of soil and nutrient loss from the hills, the productivity of hilly agricultural land will continue to decline even if forests are restored (Upadhya, 1994). The soil fertility decline and resulting impact on production has been a major concern for sustaining agricultural production in the hills of Nepal (Schreier et al., 1995). Thus, in the high-pressure hill/mountain areas sustainable soil management is a critical issue because of deteriorating soil fertility and the consequent decline in crop productivity (Tulachan and Neupane, 1999). The forest resources are important to local livelihoods and therefore, a decrease in the supply of livestock feed and litter would decrease the production of farm yard manure (FYM), which might affect the fertility and productivity of agricultural land (Giri and Katzensteiner, 2013). Soil fertility decline is not well documented in Nepal, because it is attributed to a variety of other causes such as climatic variations, changing farming practices and soil erosion. This is a complex process and it occurs when the organic content and nutrient availability decline in the soil by nutrient leaching, oxidation during humification and over use of chemical fertilizer and pesticides.

In this respect, evaluation of soil fertility and productivity and management of available resources is required. Following the works initiated by Stoorvogel and Smaling (1990), many studies indicated that nutrient balances were negative in sub-Saharan Africa (Smaling et al., 1993; Brand and Pfund, 1998; Elias et al., 1998; Van den
Bosch et al., 1998; Wortmann and Kaizzi, 1998). Truelsen and Lundsby (2001) found farm balance negative indicating a depletion of the farm nutrient stock in mid hills of Nepal.

Investigation on the contribution of forest types to sustainable livelihood of farmers is needed because the challenge lies in increasing the productivity of farms adjacent or closer to the forests, streamlining the benefits from forests towards livelihood promotion, particularly poverty alleviation (Kanel, 2004). The extraction of nutrients from the forests for farmlands is acknowledged by all but researches regarding the system of extraction, amount of nutrient being extracted, the type of products being extracted and the effect of nutrient extraction in forest are scanty. While there are attempts to document soil fertility decline, the amount of nutrient being extracted from forest for farmland is not well documented in Nepal; especially in high mountains and quantification of amount of nutrient being extracted by farmers for farm lands is rarely given much interest. Very few researches have been conducted on the amount of nutrient being extracted from the forest for the agricultural lands in mid hills and it is scarce to find documents regarding this in high mountains. Therefore, the study investigated and evaluated the contribution of forests in sustaining farm productivity through nutrient transfer in nearby farmers' fields and assessed farmers' perception on their dependence on forest litter at Lete and Kunjo, Mustang and Hemja, Kaski. This study is an effort to fill in the knowledge gap with regards to quantification of nutrients being extracted by farmers for farm lands and the system that they follow to do so.

\section{MATERIALS AND METHODS}

\section{Study area}

The study was carried out in Lete (Lete and Kalopani) and Kunjo (Chhyo, Kunjo and Taglung villge) village development committees (VDCs) of Mustang district, high mountain region and Tibrikot community forest, Hemja VDC in Kaski district, mid hills of western development region, Nepal. The study sites are shown in Figure 1.

The Mustang sites are quite representative in the context of the Himalayan and Trans-Himalayan region depicting similar natural resources and modes of subsistence (Rayamajhi, 2009). The latitude and longitude of Lete and Kalopani villages of Lete VDC are $28^{\circ} 38^{\prime} 09.1^{\prime \prime} \mathrm{N}$ and $83^{\circ} 36^{\prime} 18.1^{\prime \prime} \mathrm{E}$ and lie at $2513 \mathrm{~m}$ from mean sea level (msl). Kunjo VDC (Chhoyo, Kunjo and Taglung villages) is located east of Lete VDC between $28^{\circ} 38^{\prime} 01.5^{\prime \prime} \mathrm{N}$ and $28^{\circ} 39^{\prime} 08.9^{\prime \prime} \mathrm{N}$ latitude and longitude between $83^{\circ} 37^{\prime} 11.0^{\prime \prime}$ and $83^{\circ} 3800.2^{\prime \prime} \mathrm{E}$ at an altitude above $2400 \mathrm{~m}$ from msl.

The terrain is highly variable with grasslands in rugged steep mountain slopes, forests in mid-slopes and plateau, and cultivated river valleys. Being in a plateau and valley there is strong wind, frost and occasional snow cover. The climate is temperate to subalpine with yearly average temperature of $11.7^{\circ} \mathrm{C}(1976-1986)$ and monthly average temperature ranging between maximum $20^{\circ} \mathrm{C}$ in July and minimum $-4^{\circ} \mathrm{C}$ in February; the average annual precipitation is $1267 \mathrm{~mm}(1970-2006)$ and the rainfall peaks in June to September. 


\section{Study Areas}

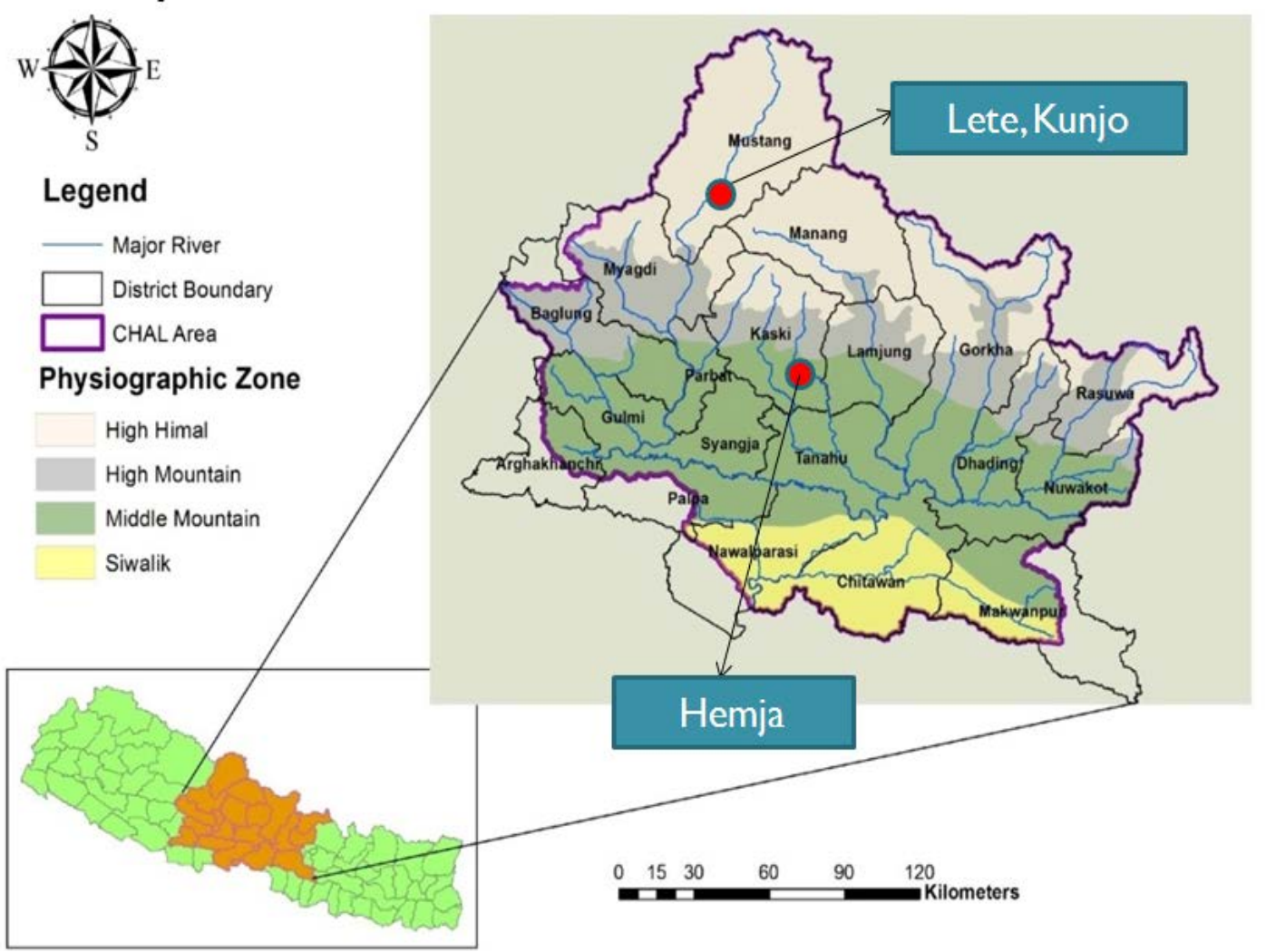

Figure 1. Location map of region showing study sites in Mustang and Kaski Districts (Modified after Gautam et al., 2012). Inset: Map of Nepal showing Narayani Basin (in brown color).

The forest is mostly temperate conifers with Pinus wallichiana as a dominant species and other genus like Rhodendron, Cupressus, Juglans, Alnus, Taxus, Hippophae, Salix, Betula, Populus, Ougenia, etc. Natural forest is the dominant land use covering about one third of the total area. Area suitable for agriculture is about $5 \%$ of the total area of which more than half is cropped and the rest is permanent fallow. Cropping and major crops grown are buckwheat, potato, naked wheat, etc. for a subsistence livelihood.

Lete covers an area of $50.8 \mathrm{~km}^{2}$ consisting of 163 households (HHs). The total population of this VDC is 899 of which 481 are male and 418 are female. Kunjo covers an area of $75.7 \mathrm{~km}^{2}$ consisting of $153 \mathrm{HHs}$. The total population of this VDC is 772 of which 421 are male and 351 are female. Rural but tourism based economy exists in Lete while rural subsistence economy exists in Kunjo.

Tibrekot community forest is situated in Hemja VDC 7, 8 and 9 in Kaski district. It is $13 \mathrm{~km}$ away from Milanchok (highway route) and is located at $28^{\circ} 16^{\prime} 53^{\prime \prime} \mathrm{N}$ latitude and $83^{\circ} 55^{\prime} 50^{\prime \prime} \mathrm{E}$ longitude. The average elevation of the site is $1000 \mathrm{~m}$ from msl. This forest was approved as a community forest on 17 August 2007. The total area of the forest is 119.75 ha located on the North-South aspect. The soil type is silty loam and silty clay loam. The forest is of mixed type consisting of Schima-Castonopsis with dominant tree species of Schima wallichii and Castonopsis indica. Other species found in the forest are Myrica esculenta, Myrsie capitellata, Holarrhena pubescens, Engelhardia spicata, Rhododendron arboretum, etc. The regeneration of forest is natural and its age is 40 years. The number of total households of the community forest is 212 with a population of 1139 . Cropping and major crops grown are paddy, potato, maize, fruits, vegetables, millet, etc. as part of semi urban: commercial production livelihood. Grazing of livestock is controlled in the community forest.

\section{Methods}

Twenty percent of the households $(n=70)$ were randomly selected from Kalopani and Lete villages of Lete whereas $30 \%$ of $\mathrm{HHs}$ $(n=68)$ from Chhyo, Kunjo and Taglung villages of Kunjo for questionnaire survey.

In Hemja, $30 \mathrm{HHs}$ out of 212 households constituting sampling intensity of $14.15 \%$ were randomly selected for the household survey. Participatory Rural Appraisal (PRA) and Rapid Rural Appraisal (RRA) tools like structured and semi-structured questionnaire, interviews, key informant survey, field observations, focused group discussion and small group meetings were also held. Key informants were selected from the people knowledgeable about the forest resources and the farm management activities. Direct observation was conducted for cross checking the information collected from household interview and other sources.

From the heap of pine leaf litter stored near the farmers' houses /livestock sheds, part of litter heap from top, bottom and middle were obtained and mixed to make a sample for analysis of nutrient content. Six of such samples of litter were collected; three from Lete and three from Kunjo. Since the litter was only of a single species ( $P$. wallichiana) and the collection sites were similar in nature (climate, soil, altitude), six samples were enough for tissue analysis which is also supported by a research conducted by Mladenoff 
et al. (2010) in which they took three samples from each individual species for tissue analysis. Similarly, six trays were used for litter and rainfall collection for Pinus radiate by Will (1959). For comparison of nutrient content (nitrogen- $\mathrm{N}$, phosphorus- $\mathrm{P}$ and potassium- K) two samples of grasses (composite sample consisting of grasses commonly used, one from Lete and one from Kunjo) as well as one sample of fern (composite sample from both Lete and Kunjo) were also collected as it was also used as bedding material for animals and ultimately used as manure as well.

In Hemja, since the forest type was Schima-Castonopsis (Schima walichii and Castonopsis indica), the litter constituted of SchimaCastonopsis of which only three composite samples were taken. Likewise, three composite samples of grass were taken for determination of NPK. Leaf litter and grass samples were analyzed to determine the nutrients (NPK) by following standard methods (AOAC, 1990). Nitrogen was determined by semi-micro Kjeldahl method (Block Digestion). Phosphorus was determined by Modified Olson (\%) direct observation taken by spectrophotometer CECIL CE7200. The potassium was determined by the flame photometer Sytronic 128.

The numbers of Bhari (head load) of litter collected by farmers were recorded while conducting questionnaire survey. The extraction of forest litter and associated nutrients for the replenishment of nutrients in farmlands were estimated from household use data collected through the questionnaire survey and average nutrient content in leaf litter samples for all sites and multiplied by percenttage dry matter to obtain the approximate amount of nutrient extracted from the forest per $\mathrm{HH}$. This method was similar to that followed by Fiegl (1989) and Schmidt (1992).

\section{RESULTS AND DISCUSSION}

\section{Socio-economic condition}

In Lete and Kunjo, most of the respondents were Thakalis (44\%) followed by Dalits (38\%) and Magars (18\%). Thakalis and Magars are ethnic communities whereas Dalits are disadvantaged community considered untouchables. The average $\mathrm{HH}$ size is 5.68 with minimum 3 and maximum 9 members. Respondents' ownership of bari-land is on an average 13.03 ropani with a minimum of 2 ropani and maximum 60 ropani area (20 ropani $=1$ ha). The crops grown include beans, potato, maize, barley, millet, buckwheat, seasonal vegetables and some farmers also grow tomatoes and carrots in plastic green houses. Some people also planted rye grass, white clover, etc. Most people $(28,82.4 \%)$ reported some problems in crop production due to diseases and pests in crops, wild animals, lack of sufficient manure, etc. Almost all respondents $(32,94.1 \%)$ have livestock that included buffaloes (8), cattle (80), pigs (7), goats (138) and poultry (255). Problems in livestock farming included diseases, lack of proper feed, wild animals' attack, lack of medicine, veterinary service, etc. $61.8 \%$ respondents had their farm production sufficient for annual consumption.

Insufficiency of farm production for consumption throughout the year indicates subsistence living and poverty of people in that area. However, in recent times, there have been some changes in the occupations of the people. Rayamajhi (2009) and CAMOP (2010) state that more than $90 \%$ people follow agriculture as their main occupation. But only $58.8 \%$ respondents were found to still conti- nue agriculture as their main and only occupa-tion. Hence, the agricultural lands are being left fallow.

In Hemja, the average family size was 5.21 with a minimum of three and maximum 11 . The majority of the people were Brahmins/Chhetri (83\%), followed by indigenous $(14 \%)$ and Dalits (3\%). Most of the people are dependent on agriculture $(73 \%)$ followed by shops/business (10\%), teaching $(10 \%)$ and governmental service $(7 \%)$ for their livelihood. $44 \%$ of $\mathrm{HHs}$ had food subsistence for 9 to 12 months, followed by $23 \%$ (3-6 months), $13 \%$ (6-9 months) and $13 \%$ (up to 3 months). The average land holding were 0.1538 ha upland-Bari and 0.2383 lowland-Khet per $\mathrm{HH}$ and the average number of livestock included 1.11 buffaloes, 1.32 cow/ox and goats 2.92.

\section{Dependency on forests}

Since most people had livestock with them and followed agriculture in Lete and Kunjo, farmers were dependent on forest in one way or the other. Most respondents (85.29\%) did not use chemical fertilizers and used only compost or FYM as the main source of manure. The main reasons for using compost instead of chemical fertilizers were its easy availability, cost and negative impacts on soil qualities (such as hardening of soil, continuous requirement, etc). However, majority of respondents (73.5\%) agreed that their dependency on forest and forest resources has decreased, had no change (17.6\%) and increased $(8.8 \%)$ as shown in Figure 2 . People are mainly dependent on forest for fuelwood, litter (for manure) and grass (for livestock). However, dependency on fuelwood has decreased due to using alternative sources of energy (such as LP gas, solar, electricity). As a result of adopting other occupations, number of livestock has decreased thus, decreasing their dependency on forest for manure and grass.

In Hemja, the majority of the respondents (60\%) as compared to $73.5 \%$ in Lete and Kunjo said that their dependency on the community forest resources has decreesed, followed by $20 \%$ constant, $13.33 \%$ increasing and $6.66 \%$ no response (Figure 2). Respondents perceived that the dependency decreased due to increasing population, decrease in livestock and agricultural land, and changing lifestyle of people.

Most of the respondents (40\%) perceived that crop production has increased because farmers have adopted new technique of farming, application of chemical fertilizers, irrigation facility, modern seed and practices. However, $26.7 \%$ respondents perceived that due to the increasing occurrences of different diseases, lack of farming skills, irrigation problem and agricultural problem, the crop production decreases.

\section{Forest products extraction system}

The secondary information and information collected through key informant survey, focused group discussion 


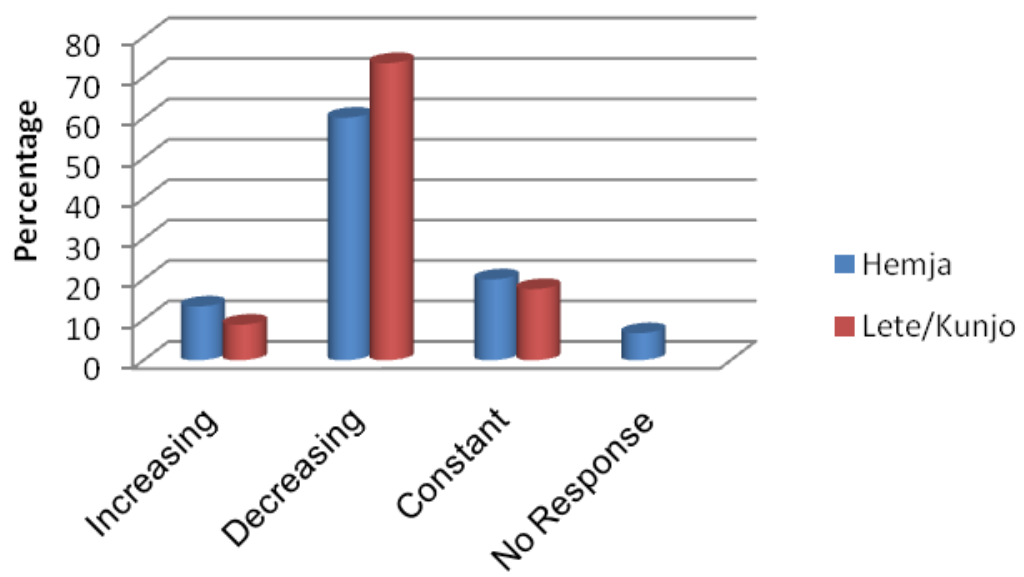

Figure 2. Peoples' perception on their dependency on forests in the study sites.

and small group meetings were used to know the details of forest products extraction systems. The management of the area is the responsibility of a non-political VDC Conservation Area Management Committees (CAMCs) in Lete and Kunjo. Each VDC level local government chairperson (sometimes secretary) is represented in the CAMC as a member for ensuring coordination. Each CAMC has a written constitution and operational plan for regulating the use of the forest and other natural resources. There are three subcommittees under CAMC main committee consisting of the village Mukhiyas (chief) as members. Both CAMC and Mukhiyas play important role in regulating and controlling extraction of forest products mainly leaf litter and seabuckthorn fruit. The Mukhiya system has been legally abolished in 1956 (2013 BS) after the dawn of democracy. But it is still largely accepted and practiced in the study area.

Period for collecting the sanpat (pine litter) from the forest is fixed for about a week during the winter generally after the first flush of snow. Leaf litter collection is allowed from mid-December ( $1^{\text {st }}$ of Paush) during which a maximum of three persons from each $\mathrm{HH}$ are allowed to collect pine litter for only 5 days in Lete. In Kunjo, pine litter collection starts in late autumn or early winter but there is no time limitation. The forests are difficult to access and heavy snowfall starts shortly after the winter begins. Hence, the time for extraction is regulated naturally. Violators of collection period get strong punishment that is decided by the Mukhiya. The pine litter collected is stored in heaps near the houses and animal sheds.

In Hemja, the studied forest- Tibrikot community forest is controlled and regulated following its operational plan and constitution. Every user must obey the rules and regulations as prescribed in the operational plan and constitution. The condition of forest was good and it was revealed that the users strictly followed operational plan and constitution of the community forest. People were dependent on forest for fuelwood, grass, fodder and leaf litter collection. The forest is opened for 10 days in AprilMay during which users are allowed to collect leaf-litter; while grass collection is allowed twice a year for about 10 days, during May-June and July-August.

\section{Nutrient content and transfer}

In Lete, the amount of litter extracted was 23.28 bhari per $\mathrm{HH}$ (1 bhari $=25 \mathrm{~kg}$ ), which was almost same (25 bhari) as mentioned in CAM operational plan (OP). In Kunjo, the average litter collected was 86.5 bhari per $\mathrm{HH}$, which was comparatively lower than mentioned in CAMOP of 200 bhari. This might be due to the decreasing number of people involved in agriculture in Lete and Kunjo and increasing involvement of people from other villages in extracting more litter. Only $8.82 \%$ people collected small amount of fodder and grass from the forest to stall-feed their cattle during winter. Most of the respondents let their cattle in the forest during the monsoon season. Farmers collected on an average 85.29 mutha of grass from farmlands and wastelands per year ( 1 mutha $=5 \mathrm{~kg}$ ).

The nutrient content of the pine leaf litter was in the range of 0.70 to $1.53 \% \mathrm{~N}, 0.086$ to $0.138 \% \mathrm{P}$ and 0.603 to $0.807 \% \mathrm{~K}$. The nutrient content of grass samples and fern samples were higher than that of litter samples. However, grass and fern could not be stored for long and not found abundantly in all seasons. Fern was found to be used as bedding material. Grass was primarily used for feeding purposes rather than as bedding material. Hence, pine litter was the most suitable for making compost by mixing with animal dung and urine.

The average amounts of $\mathrm{N}, \mathrm{P}$ and $\mathrm{K}$ extracted by each $\mathrm{HH}$ were $3.84,2.99$ and $0.54 \mathrm{~kg}$ corresponding to the transfer of $4.82,0.62$ and $3.75 \mathrm{~kg}$ per ha, respectively, through pine litter only in Lete. If all $70 \mathrm{HHs}$ collected same quantity of litter, then about $268.8 \mathrm{~N}, 209.3 \mathrm{P}$ and $37.8 \mathrm{~kg} \mathrm{~K}$ would be extracted per year in Lete (Figure 3). 


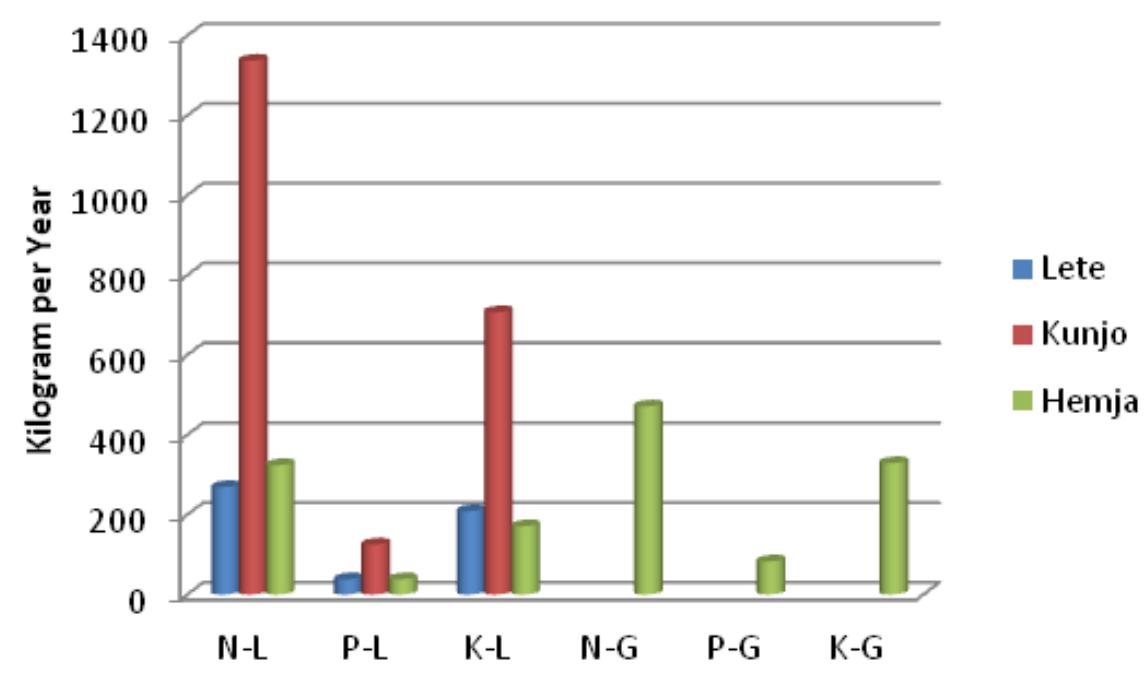

Figure 3. total npk extracted per year in the study sites. Note: $N$ (nitrogen), $P$ (phosphorus), K (potasium), L (leaf litter) and G (grass).

Table 1. Average forest litter and grass collection per household (Bhari/Year) in two eco-regions.

\begin{tabular}{|c|c|c|c|c|c|c|}
\hline & Study Site & $\mathbf{N}$ & Mean & $\begin{array}{c}\text { Std. } \\
\text { deviation }\end{array}$ & $\begin{array}{l}\text { Std. error } \\
\text { mean }\end{array}$ & p- Value \\
\hline \multirow{2}{*}{$\begin{array}{l}\text { Litter collected from } \\
\text { forest in bhari per } \\
\text { year }\end{array}$} & High mountain & 34 & $54.9 * \star$ & 41.979 & 7.199 & \multirow[t]{2}{*}{0.001} \\
\hline & Mid mountain & 30 & 8.27 & 5.246 & .958 & \\
\hline \multirow{2}{*}{$\begin{array}{l}\text { Grass collected from } \\
\text { forest in bhari per } \\
\text { year }\end{array}$} & High mountain & 34 & 7.71 & 28.040 & 4.809 & \multirow[t]{2}{*}{0.299} \\
\hline & Mid mountain & 30 & 14.93 & 10.761 & 1.965 & \\
\hline
\end{tabular}

Independent T- test; 1 bhari $=25 \mathrm{~kg}$ fresh biomass.

However, the average amount of N, P and $\mathrm{K}$ extracted by each $\mathrm{HH}$ were $19.66,1.84$ and $10.39 \mathrm{~kg}$, respectively (35.75 N, $3.35 \mathrm{P}$ and $18.89 \mathrm{~kg} \mathrm{~K}$ per ha) in Kunjo, which would translate to total quantity of about $1336.88 \mathrm{~N}$, $125.12 \mathrm{~g} \mathrm{P}$ and $706.52 \mathrm{~kg} \mathrm{~K}$ extracted per year. The nutrient extracted per year in both study sites are shown in Figure 3.

In Hemja, the total amount of leaf-litter of SchimaCastonopsis and grass collected were 250 and $612 \mathrm{~kg}$ per HH per year, respectively. The average nutrient- $\mathrm{N}, \mathrm{P}$ and $\mathrm{K}$ content in the leaf litter of Schima-Castonopsis species were 1.5, 0.177 and $0.797 \%$, and in grass were $0.94,0.167$ and $0.66 \%$, respectively. The average nutrients transferred from the forest to farmlands by each households through leaf litter were $1.53 \mathrm{~N}, 0.18 \mathrm{P}$ and $0.81 \mathrm{~kg} \mathrm{~K}(28.26 \mathrm{~N}, 3.21 \mathrm{P}$ and $14.95 \mathrm{~kg} \mathrm{~K}$ per ha and through grass were $2.22 \mathrm{~N}, 0.39 \mathrm{P}$ and $1.55 \mathrm{~kg} \mathrm{~K}(16.22$ $\mathrm{N}, 2.22 \mathrm{P}$ and $11.42 \mathrm{~kg} \mathrm{~K}$ per ha) which would translate to total quantity of about $324.4 \mathrm{~N}, 38.2 \mathrm{P}$ and $171.7 \mathrm{~kg} \mathrm{~K}$ extracted per year through leaf litter and $470.6 \mathrm{~N}, 82.7 \mathrm{P}$ and $328.6 \mathrm{~kg} \mathrm{~K}$ through grass (Figure 3 ).

Data collected from the HHs (Table 1) showed that the main source of plant nutrients in Lete and Kunjo (high mountain) was pine litter collected from the forest. The farmers in high mountain collected significantly higher amount of forest litter as a nutrient source (54.9 Bhari/yr/HH) as compared to Hemja (mid mountain). It means high mountain farmers are more dependent on forest for nutrients supply for crop production. However, there was no significant difference in collection of grasses between two regions. It is due to the dominant pine forest in the high mountain where grass does not grow well for collection to feed livestock.

The analysis of the pine litter collection in Lete and Kunjo in the high mountain region (Table 2) showed that Kunjo farmers collected significantly higher amount of pine litter as compared to the farmers in Lete. The lower amount of litter collected by the farmers in Lete is due to its location as the tourist trek area and local people depending on hotel business rather than farming as compared to Kunjo.

The nutrient content determined in pine litter samples was similar to the nutrient content mentioned by different researchers. Singh (2011) reported 1.14N, 0.25P and 0.22\% 
Table 2. Average pine litter collection per household (Bhari/year) in Lete and Kunjo.

\begin{tabular}{llllccc}
\hline & Studied VDCs & $\mathbf{N}$ & Mean & Standard deviation & Standard error mean & p-Value \\
\hline $\begin{array}{l}\text { Litter collected from } \\
\text { forest in bhari per }\end{array}$ & Lete & 14 & 23.29 & 8.033 & 2.147 & 0.001 \\
year & Kunjo & 20 & $86.50^{* *}$ & 35.840 & 8.014 & \\
\hline
\end{tabular}

Independent samples t- Test.

$\mathrm{K}$ content in pine litter in mid hills of Nepal. Roder (1990) reported $0.81 \mathrm{~N}, 0.05 \mathrm{P}$ and $0.27 \% \mathrm{~K}$ content in Pinus wallichiana litter above $2500 \mathrm{~m}$ in Bhutan. Similarly, Siddiqui et al. (2000) found that nutrient contents in Pinus leaf litter above $2500 \mathrm{~m}$ were $1.585 \pm 0.715 \% \mathrm{~N}, 0.785 \pm$ $0.035 \% \mathrm{P}$ and $0.57 \pm 0.23 \% \mathrm{~K}$.

Large amounts of compost are produced from a mixture of livestock manure, forest leaf-litter and farm waste. Animal manure combined with large quantities of forest products collected for animal bedding and fodder accounts for a considerable proportion of nutrient supply to crops (Yadav, 1992). Khadka et al. (1984) reported that $50 \%$ of the litter is removed from the forests of the mid-hills annually for manuring purposes. Soil fertility under the traditional farming system has been maintained by repeated addition of various amounts of organic compost/ manure, ranging from 3 to $21 \mathrm{mt}$ per ha per annum (Heuch, 1986). Animal fodder and leaf litter for compost production are in high demand and account for $31 \mathrm{~kg} \mathrm{~N} / \mathrm{ha}$ and $53 \mathrm{~kg}$ bases/ha removed annually (Brown, 1997). Giri and Katzensteiner (2013) found that 39-40 kg N per ha was applied to arable land as FYM. The study findings show that $\mathrm{N}$ applications in Kunjo and Hemja through leaf litter are almost similar whereas in Lete, it is much lower. Farming activities, such as collection of forest fodder and litter for livestock feed, bedding, and the making of compost, which was eventually applied to Bari and Khet land as a nutrient source, are likely to have led to low soil organic carbon accumulation in the forest and the enrichment of Bari land (Tiwari et al., 2010). However, chemical fertilizer uses have increased by about $11.5 \mathrm{~kg}$ per ha annually in Nepal but, purchase of high priced chemical fertilizer is very difficult for marginal farmers of hills and mountains (NARMA, 2011). Therefore, it is suggested to use both organic and inorganic sources of plant nutrients for sustaining the productivity for a wide range of cropping patterns (Sherchan et al., 1999; Tripathi, 2001).

\section{Conclusion}

The farmers of Lete and Kunjo extracted on an average 582 and $2162.5 \mathrm{~kg}$ leaf litter (of Pinus wallichiana) as main source of composting material in their farm land after mixing with animal dung and urine. The amount of fodder and grass extracted in the study area was negligible. The amount of $\mathrm{N}, \mathrm{P}$ and $\mathrm{K}$ extracted per $\mathrm{HH}$ per year was estimated at $3.84,2.99$ and $0.54 \mathrm{~kg}$ in Lete VDC (Lete and Kalopani) and 19.66, 1.84 and $10.39 \mathrm{~kg}$ in
Kunjo VDC (Chhyo, Kunjo and Taglung). People of Kunjo depended more on agriculture and hence extracted more $\mathrm{N}, \mathrm{P}$ and $\mathrm{K}$ from the forest. The extraction of forest products was regulated by the CAMC and Mukhyas of the study area. The farmers of the study area relied heavily upon forest resources for maintaining soil fertility of their farmlands. Due to difficult access, expensive price and observed negative impacts of chemical fertilizers, most respondents (85.29\%) refrained from using chemical fertilizers and used compost or FYM only. $14.71 \%$ of the respondents only used chemical fertilizers in small quantities in addition to forest leaf litter to maintain the fertility of their land.

In Hemja, the total amount of leaf-litter of mainly Schima-Castonopsis and grass collected by each household were 250 and $612 \mathrm{~kg}$ per year, respectively. The leaf litter transferred the total amount of $1.53 \mathrm{~N}, 0.18$ $\mathrm{P}$ and $0.81 \mathrm{~kg} \mathrm{~K}$ to farmland by each household and in the form of grass, $2.22 \mathrm{~N}, 0.39 \mathrm{P}$ and $1.55 \mathrm{~kg} \mathrm{~K}$. Peoples' dependency on forest was found to be in decreasing trend due to the changing lifestyle of people.

Realizing the importance of fodder, grass and leaf-litter in nutrients transformations, the information on flow of nutrients and their balance in farm-forest interface can be used for future management of forests and farming systems for their sustainable production. To what extent the amount of nutrients is being extracted, the removal of litter and wood/forest products on forest site productivity, nutrient balances, and other site characteristics affect the functional aspect of forest ecosystem which is still ambiguous and need a detail study in the Nepalese context. Significant improvement in soil fertility and thereby increasing the crop productivity can be achieved as the benefits of integrated nutrient management with the use of some amount of inorganic fertilizers to supplement part of plant nutrients required by various cropping systems and thereby fulfilling the nutrient gap.

\section{ACKNOWLEDGEMENTS}

The authors are thankful to all the farmers of Lete/Kunjo and Hemja for sparing their time and knowledge during questionnaire survey and discussions, ComForM Project IOF for the financial support to conduct the study and LIBIRD for analyzing the litter and grass samples.

Acknowledgement is also due to ComForM Project and Dean, IOF for providing travel support to the first author 
for paper presentation in the $8^{\text {th }}$ Himalayan Policy Research Conference, Madison, Wisconsin under the international conference participation.

\section{REFERENCES}

Aase HT, Chapagain PS, Tiwari PC (2013). Innovation as an expression of adaptive capacity to change in Himalayan farming. Mt. Res. Dev. 33(1): 4-10.

Aase HT, Chaudhary RP, Veetas OR (2009). Farming flexibility and food security under climatic uncertainty: Manang, Nepal Himalaya. Area 42(2): 228-238.

AOAC (1990). Official Methods of Analysis. Association of Official Analytical Chemists. $15^{\text {th }}$ Ed., NPK analysis, Gaithersburg, Maryland, USA.

Brand J, Pfund JL (1998). Site- and watershed-level assessment of nutrient dynamics under shifting cultivation in Eastern Madagascar. Agric. Ecosyst. Environ. 71:169-183.

Brown S (1997). Soil Fertility, Nutrient Dynamics and Socio-Economic Interactions in the Middle Mountains of Nepal. PhD. Thesis, Interdisciplinary Studies in Resource Management Science, University of British Columbia.

CAMOP (2010). Conservation Area Management Operational Plans.

CBS (2005). Central Bureau of Statistics. HMG/N, Kathmandu.

Denholm J (1991). Agroforestry in Mountain Areas of the Hindu KushHimalayan Region. ICIMOD Occasional paper no. 17. International Center for Integrated Mountain Development, Kathmandu, Nepal.

Elias E, Morse S, Belshaw DGR (1998). Nitrogen and phosphorus balances in Kindo Koisha Farms in Southern Ethiopia. Agric. Ecosyst. Environ. 71: 93-113.

Fiegl F (1989). Preliminary Assessment of Forest and Forest Soil Properties in the Lower Jhikhu Khola Watershed, Nepal. Diploma, Ludwig-Maximillian University.

Gautam AP, Thapa BR, Pandit BH, Dhungana BM, Tiwari KR, Neupane MP, Balla MK, Joshi MR, Sharma UR (2012). Rapid Assessment of Chitwan-Annapurna Landscape. Hariyo Ban Program, WWF Nepal, Kathmandu, Nepal.

Gilmour DA (1989). Forest Resources and Indigenous Management in Nepal. Working Paper No.17, East West Center, Honolulu, Hawaii.

Giri A, Katzensteiner K (2013). Carbon and nitrogen flow in the traditional land use system of the Himalaya region, Nepal. Mt. Res. Dev. 33(4): 381-390.

Griffin DM, Shepherd KR, Mahat TBS (1988). Human impact on some forests of the Middle Hills of Nepal. Part 5. Comparisons, concepts and some policy implications. Mt. Res. Dev. 8(1): 43-52.

Heuch J (1986). Fodder for foresters - an introduction to tree fodder use in Nepal. LAC Technical Paper 86113, LAC, Kaski. p.17. http://dx.doi.org/10.1111/j.1475-4762.2009.00911.x.

Kadaria RK (1992). The development of sustainable livestock production systems in the Mid Hills of Nepal, based upon agroforestry concepts. LAC Seminar Paper No. 1992/16, LAC, Pokhara, Nepal.

Kadaria RK (1994). Development of sustainable livestock production system in the Middle Hills of Nepal, based upon agroforestry concepts. Proceeding of the Regional Expert Consultation on Farmer to Farmer Adaptive Agroforestry Research. APAN report no. 12.

Kanel KR (2004). Twenty five years' of community forestry: Contribution to millennium development goals. Proceedings of the Fourth National Community Forestry Workshop, Kathmandu, August 4-6, 2004, Department of Forest, Kathmandu, Nepal.

Khadka RJ, Shrestha J, Tamrakar AS (1984). Ecology of Godawari. In T.C. Majpuria (ed) Nepal - Nature's Paradise, White Lotus Co. Bangkok, Thailand. pp 408-437.

Mahat TBS (1987). Forestry Farming Linkages in the Mountain. ICIMOD Occasional Paper No.7, ICIMOD, Kathmandu, Nepal.

Mladenoff DJ, Forrester JA, Schatz J (2010). Impacts of Biomass Removal on Carbon and Nutrient Pools in Wisconsin Northern Harwood Forests: Establishment of a Long-Term Study. University of Wisconsin, Madison, Wisconsin.

NARMA (2011). Training and Community Facilitation on Use of Fertilizers and Seeds in Nepal. NARMA Consultancy Pvt. Ltd, Baneswar, Kathmandu.
Pilbeam CJ, Tripathi BP, Sherchan DP, Gregory PJ, Gaunt J (2000). Nitrogen balances for households in the mid-hills of Nepal. Agric. Ecosyst. Environ. 79: 61-72.

Rayamajhi S (2009). Forest Dependency, Livelihoods and Conservation of High Altitude Forests in Nepal. Ph.D. Dissertation. Faculty of Life Sciences, University of Copenhagen, Copenhagen, Denmark.

Roder W (1990). Traditional Use of Nutrient Inputs. Agriculture Research Center, Yusipang, Bhutan.

Schmidt M (1992). GIS Evaluation of Forest Dynamics and Forest Soil Fertility in a Mountain Watershed in Nepal. Ph.D. Thesis, University of British Columbia, British Columbia, Canada.

Schreier H, Brown S, Shah PB (1995). Identification of key resource issues: Discussions and recommendations. In H. Schreier, P.B. Shah and S. Brown (eds.) Challenges in Mountain Resources Management in Nepal: Processes, Trends and Dynamics in Middle Mountain Watershed, Proceedings of Workshop, held in Kathmandu, ICIMOD, Kathmandu.

Sherchan DP, Pilbeam CJ, Gregory PJ (1999). Response of wheat-rice and maize/millet systems to fertilizer and manure applications in the mid hills of Nepal. Exp. Agric. 35:1-13.

Siddiqui FM, Ahmed M, Shaukat SS, Ajaib M (2000). Soil and foliar nutrients concentration of conifer species in the communities of moist temperate areas of Southern Himalayan and Hindukush Region of Pakistan. FUUAST Journal of Biology, Federal Urdu University for Arts, Science and Technology.

Singh A (2011). Nutrients Input through Pine and Schima Leaf Litter in Community Forest. B.Sc. Forestry Project Paper, IOF, Hetauda Campus, Hetauda, Nepal.

Smaling EMA, Stoorvogel JJ, Windmeijer PN (1993). Calculating soil nutrient balances in Africa at different scales II. District scales. Fertil. Res. 35: 237-250.

Stoorvogel JJ, Smaling EMA (1990). Assessment of Soil Nutrient Depletion in Sub-Saharan Africa. Report 28, Winand Staring Centre, Wageningen, Netherlands.

Thapa GB, Weber KE (1995). Status of management of watersheds in the upper Pokhara Valley, Nepal. Environ. Manage. 19(4): 497-513.

Tiwari KR, Sitaula BK, Bajracharya RM, Borassen T (2010). Effect of soil and crop management practices on yields, income and nutrients losses from upland farming systems in the middle mountains region of Nepal. Nutr. Cycling Agroecosyst. 86: 241-253.

Tripathi BP (2001). Enhancement of Fertility and Crop Productivity for Acidic Soils in the Hills of Nepal. Lumle Technical Paper No. 2001/2, Agriculture Research Station, Lumle, P.O. Box 1, Pokhara, Nepal.

Truelsen OM, Poul L (2001). Application of the Nutrient Balance Concept to the Traditional Subsistence Farming System in the Middle Hills of Nepal: A Case Study from Dhola VDC, Dhading District. Master Thesis, Department of Agricultural Sciences, Royal Veterinary and Agricultural University, Copenhagen, Denmark.

Tulachan PM, Neupane A (1999). Livestock in Mixed Farming Systems of the Hindu Kush Himalayas - Trends and Sustainability. FAO/ICIMOD, Kathmandu.

Upadhya M (1994). Restoring Mountainous Region: A Strategy at the Local Level. BWMP, Kathmandu.

Van den Bosch H, Gitari JN, Ogaro VN, Maobe S, Vlaming J (1998). Monitoring nutrient flows and economic performance in African farming systems (NUTMON), III. Monitoring nutrient flows and balances in three districts in Kenya. Agric. Ecosyst. Environ. 71:63-80.

Will GM (1959). Nutrient return in litter and rainfall under some exotic conifer stands in New Zealand. Forest Research Institute, Rotorua. First published 12 Jan, 2012.Downloaded on 3 Nov 2012 from http://www.tandfonline.com/loi/tnza20.

Wortmann CS, Kaizzi CK (1998). Nutrient balances and expected effects of alternative practices in farming systems of Uganda. Agric. Syst. Environ. 71: 115-129.

Wyatt-Smith J (1982). The Agricultural System in the Hills of Nepal: The Ratio of Agricultural to Forest Land and the Problem of Animal Fodder. APROSC Occasional Papers, Agricultural Projects Services Centre, Kathmandu, Nepal.

Yadav Y (1992). Farming-forestry-livestock linkages: A component of mountain farmers' strategies (Nepal). In N.S. Jodha, M. Banskota and T. Partap (Eds) Sustainable Mountain Agriculture. Vol 1. Perspectives and Issues. Intermediate Technology Publications, London, UK. 